Abstracta Iranica Abstracta Iranica

Revue bibliographique pour le domaine irano-aryen

Volume 25 | 2004

Comptes rendus des publications de 2002

\title{
Morgenland und Abendland - Mein west-östliches Leben. München, C.H.Beck, 2002, 352 p.
}

\section{Pierre Lory}

\section{OpenEdition}

1 Journals

Édition électronique

URL : http://journals.openedition.org/abstractairanica/4884

DOI : $10.4000 /$ abstractairanica.4884

ISSN : 1961-960X

\section{Éditeur :}

CNRS (UMR 7528 Mondes iraniens et indiens), Éditions de l'IFRI

\section{Édition imprimée}

Date de publication : 15 mai 2004

ISSN : 0240-8910

\section{Référence électronique}

Pierre Lory, «Morgenland und Abendland - Mein west-östliches Leben. München, C.H.Beck, 2002, 352 p. », Abstracta Iranica [En ligne], Volume 25 | 2004, document 251, mis en ligne le 15 mars 2006 consulté le 25 septembre 2020. URL : http://journals.openedition.org/abstractairanica/4884 ; DOI : https://doi.org/10.4000/abstractairanica.4884

Ce document a été généré automatiquement le 25 septembre 2020.

Tous droits réservés 


\title{
Morgenland und Abendland - Mein west-östliches Leben. München, C.H.Beck, 2002, 352 p.
}

\author{
Pierre Lory
}

1 Dans cet ouvrage, la célèbre orientaliste allemande dresse son autobiographie, racontant comment une jeune élève d'une ville moyenne allemande s'est intéressée à la culture orientale, sans raison de départ particulière, et a connu un cursus universitaire fulgurant. A.S. y fait part de ses voyages, de ses très nombreuses rencontres sur les trois continents, jusqu'en 2002, soit l'année précédant son décès. Elle s'y raconte elle-même dans son vécu personnel, et le livre ne contient guère de réflexions ou réactions sur les sociétés musulmanes, leur situations politiques ou culturelles, ni même leur spiritualité à laquelle l'A. s'est pourtant tant consacrée.

\section{INDEX}

Thèmes : 7. Islam

\section{AUTEURS}

PIERRE LORY

EPHE - Paris 